\title{
Annual Cycle of Poleward Heat Transport in the Ocean: Results from High-Resolution Modeling of the North and Equatorial Atlantic
}

\author{
Claus W. Boning and Peter Herrmann \\ Institut für Meereskunde an der Universität Kiel, Kiel, Germany \\ (Manuscript received 13 October 1992, in final form 23 March 1993)
}

\begin{abstract}
The annual cycle of meridional heat transport in the North and equatorial Atlantic Ocean is studied by means of the high-resolution numerical model that had been developed in recent years as a Community Modeling Effort for the World Ocean Circulation Experiment. Similar to previous model studies, there is a winter maximum in northward heat transport in the equatorial Atlantic and a summer maximum in midlatitudes. The seasonal variation in heat transport in the equatorial Atlantic, with a maximum near $8^{\circ} \mathrm{N}$, is associated with the out-ofphase changes in heat content to the north and south of that latitude in connection with the seasonal reversal of the North Equatorial Countercurrent. The amplitude of the heat transport variation at $8^{\circ} \mathrm{N}$ depends on model resolution: forcing with the monthly mean wind stresses of Hellerman-Rosenstein (HR) gives an annual range of $2.1 \mathrm{PW}$ in the case of a $1 / 3^{\circ}$ meridional grid, and $1.7 \mathrm{PW}$ in the case of a $1^{\circ}$ grid, compared to 1.4 PW in a previous $2^{\circ}$ model. Forcing with the wind stresses of Isemer-Hasse (IH) gives $2.5 \mathrm{PW}$ in the $1 / 3^{\circ}$ and $2.2 \mathrm{PW}$ in the $1^{\circ}$ model case. The annual range of heat transport in the subtropical North Atlantic is much less dependent on resolution but sensitive to the wind stress: it increases from $0.5 \mathrm{PW}$ in the case of $\mathrm{HR}$ forcing to almost $0.8 \mathrm{PW}$ with IH forcing.

The annual cycle of heat transport can be understood in terms of wind-driven variations in the meridional overturning; variations in horizontal gyre transport have only little effect both in the equatorial and in the subtropical Atlantic. In all model solutions the seasonal variations in the near-surface meridional Ekman transport are associated with deep seasonal overturning cells. The weak shear of the deep response suggests that the large variations in heat transport on seasonal and shorter time scales should be of little consequence for observational estimates of mean oceanic heat transports relying on one-time hydrographic surveys.
\end{abstract}

\section{Introduction}

The poleward transport of energy in the atmosphere and oceans represents an essential factor in the annual mean global heat budget and serves to maintain the global thermal equilibrium. Increasing efforts have gone into developing a better understanding of the quantitative role of the ocean since the revolutionary study of Vonder Haar and Oort (1973) had shown that a large fraction of total poleward transport in low latitudes must be carried by the ocean circulation. However, there are still considerable uncertainties due to the limited ocean database. The direct method to calculate the meridional transport of heat in the ocean is based on transoceanic, zonal hydrographic sections, coupled with current measurements near the boundaries. Such "heat flux lines" constitute an essential part of the observational program of the World Ocean Circulation Experiment (WOCE). An as yet unsettled issue concerns the representativeness of heat transport

Corresponding author address: Dr. Claus W. Böning, Institut für Meereskunde an der Universität Kiel, Düsternbrooker Weg 20, D24105 Kiel, Germany. values from one-time surveys. In particular, the annual variation in northward heat transport is controversial.

A huge annual cycle of ocean heat transport had been indicated by the studies of Oort and Vonder Haar (1976) and Carrissimo et al. (1985). Their indirect estimates were based on the radiation balance at the top of the atmosphere, atmospheric transports calculated from radiosonde data, and oceanic heat storage changes calculated from hydrographic data. The heat transports in the ocean derived in this way were directed from the summer to the winter hemisphere, with an annual range exceeding $7 \mathrm{PW}$ at the equator and $5 \mathrm{PW}$ at $25^{\circ} \mathrm{N}\left(1 \mathrm{PW}=10^{15} \mathrm{~W}\right)$ (Fig. 1a). First clues to the mechanism of these annual changes were obtained in a model study of Bryan and Lewis (1979), henceforth referred to as BL. The global BL model also showed a winter maximum of northward heat transport in the tropical ocean, but in contrast to the former observations a weak summer maximum in midlatitudes (Figs. $1 \mathrm{~b}, \mathrm{c})$. The forcing of the BL model included only the first annual harmonic of the climatological wind stresses compiled by Hellerman (1967). Later studies, notably the global model of Meehl et al. (1982) and the Atlantic model of Sarmiento (1986, hereafter S), confirmed the principal feature of BL, that is, the op- 

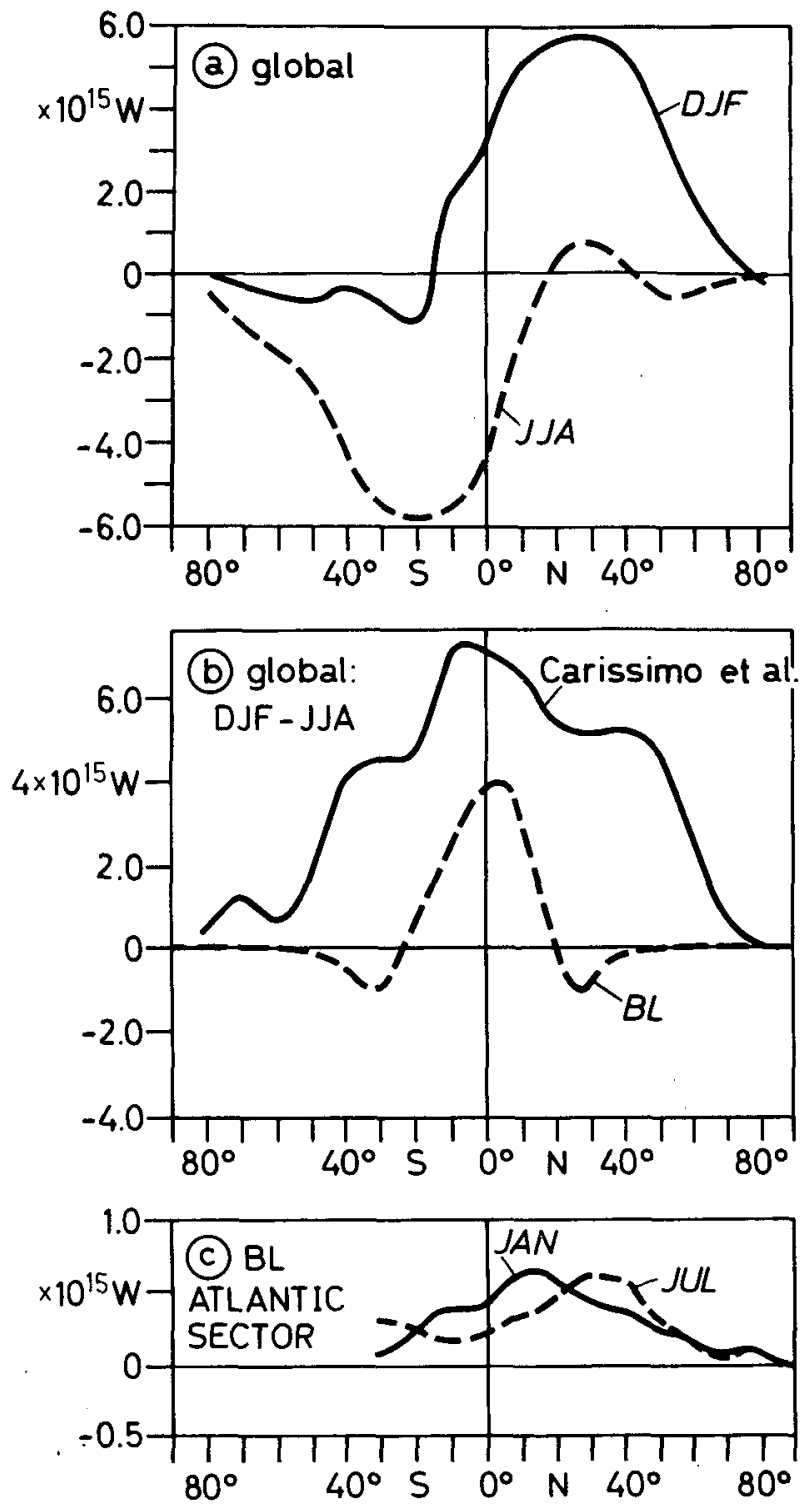

FIG. 1. (a) Northward heat transport in the World Ocean during winter (DJF) and summer (JJA), from the analysis of Carissimo et al. (1985); (b) difference between their winter and summer transports, compared to the model result of BL; (c) the BL result for the Atlantic sector of their World Ocean model, from the analysis of Bryan (1982).

posite phases of the annual cycle in the tropics and subtropics, but also emphasized the significance of a more detailed representation of the wind stress. With the monthly mean wind stresses of Hellerman and Rosenstein (1983; henceforth HR), S obtained much larger annual ranges compared to the Atlantic sector results from the $\mathrm{BL}$ model. Maximum values in the equatorial Atlantic, between $5^{\circ}$ and $10^{\circ} \mathrm{N}$, were about 1.4 PW, and in midlatitudes, about $0.4 \mathrm{PW}$.

In recent years, an annual cycle of northward ocean heat transport qualitatively corresponding to the model patterns of $B L$ and $S$, that is, with a summer maximum in the subtropics, had been obtained by two different observational studies. Following earlier attempts by Lamb (1981) and Lamb and Bunker (1982), Hsiung et al. (1989) calculated seasonal oceanic heat transports indirectly from computations of the air-sea heat exchange and estimates of heat storage. Molinari et al. (1990) applied the direct method of Hall and Bryden (1982) to the monthly mean climatological data of Levitus (1982) for the Atlantic Ocean at $26.5^{\circ} \mathrm{N}$ where the seasonal variability of the western boundary current is fairly well known from observations. The annual cycle obtained in these studies for the subtropical North Atlantic is shown in Fig. 2. One certainly has to account for a large error of the single monthly values ( 0.4 or $0.5 \mathrm{PW}$ as given by the authors), which may explain the unrealistically large month-to-month variability. An interesting feature, however, is that both studies indicate a minimum of northward heat transport in winter and a more or less broad maximum in summer. That variation is in qualitative accordance with the model simulations. However, the annual range of about $1 \mathrm{PW}$ is twice as large as that of $\mathrm{S}$ and about four times as in BL; it is nearly as large as the mean northward transport of 1.2 PW obtained by Hall and Bryden (1982) and Roemmich and Wunsch (1985) from hydrographic sections at $24.5^{\circ} \mathrm{N}$.

As had been demonstrated especially in Bryan's (1982) analysis of the BL results, the prime cause for the annual cycle of heat transport in the model solution is the variation of zonal wind stress. The corresponding changes in the meridional Ekman transport were associated in the BL model with deep seasonal overturning cells in the meridional-vertical plane (Bryan 1982). Some attempts have been made in recent years to calculate the effect of seasonal changes in wind stress on the meridional heat transport in the ocean. However, the role of variations in meridional Ekman transport is controversial, since assumptions have to be made about the vertical structure and, thus, temperature of

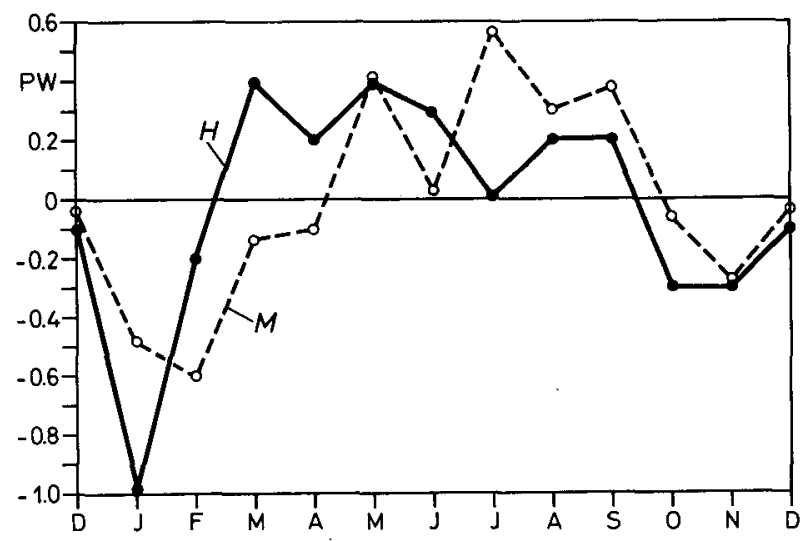

FIG. 2. Annual cycle of northward heat transport in the subtropical North Atlantic $\left(25^{\circ} \mathrm{N} / 26.5^{\circ} \mathrm{N}\right)$ : monthly values of $(\mathrm{H})$ Hsiung et al. (1989) and (M) of Molinari et al. (1990). 
the compensatory flow at depth. While Kraus and Levitus (1986) assumed implicitly that Ekman transport variations are compensated by transport anomalies in the deep ocean, Bryden et al. (1991) thought it was more reasonable to assume that seasonal circulation changes are confined to the upper $700 \mathrm{~m}$ of the ocean. Thus, despite of their similar values for the seasonal changes in the wind-driven volume transport, Kraus and Levitus (1986) and Bryden et al. (1991) arrived at widely differing conclusions about the associated variations in meridional heat transport.

The annual cycle of poleward heat transport is studied here by means of a high-resolution model of the wind-driven and thermohaline circulation in the Atlantic Ocean. The model had been developed in recent years as a community modeling effort (CME) for WOCE. After the implementation of the model and an initial spinup experiment by Bryan and Holland (1989) at the National Center for Atmospheric Research (NCAR), a number of runs have been conducted both at NCAR and IfM Kiel, differing in resolution, friction, wind forcing, mixed-layer dynamics, and boundary conditions. Various model evaluations have been concerned with the seasonal variability of the current system in different parts of the Atlantic. These indicated a fairly realistic simulation of the salient features of the vigorous seasonal circulation changes in the equatorial Atlantic (Schott and Böning 1991; Didden and Schott 1992). Böning et al. (1991a) had studied the annual cycle of the western boundary currents in the subtropical North Atlantic. They found a strong influence of the wind stress climatology on the annual amplitude of the volume transport through the Florida Straits as well as on the amplitude of the zonally integrated heat transport in the North Atlantic. In the present study we are concerned with the mechanism of the heat transport variations and their contribution to changes in heat storage in various parts of the North and equatorial Atlantic.

\section{The model experiments}

The CME model configuration has been developed by Bryan and Holland (1989) based on the primitive equation model described by Bryan (1969) and Cox (1984). The first experiment performed at NCAR was a 25-year simulation of the wind-driven and thermohaline circulation in the Atlantic Ocean starting from initial conditions given by the climatology of Levitus (1982). The model domain extends from $15^{\circ} \mathrm{S}$ to $65^{\circ} \mathrm{N}$, and the grid spacing is $1 / 3^{\circ}$ in meridional and $0.4^{\circ}$ in zonal direction. In the vertical 30 levels are used, with a vertical spacing smoothly increasing from $35 \mathrm{~m}$ at the surface to $100 \mathrm{~m}$ near the depth of $500 \mathrm{~m}$ and $250 \mathrm{~m}$ below $1000 \mathrm{~m}$. For further details of the model configuration and a description of the different experiments, the reader is referred to Bryan and Holland (1989) and Böning et al. (1991a).
The thermohaline circulation is driven by a relaxation of surface salinity to the monthly mean values of Levitus on a time scale of 50 days and a linear bulk formula for the surface heat flux. Following Haney (1971), the downward heat flux across the ocean surface $Q$ can be expressed as

$$
Q=Q_{1}+Q_{2}\left(T_{A}-T_{S}\right),
$$

where $T_{A}$ is an atmospheric equilibrium temperature and $T_{S}$ the sea surface temperature. The coefficient $Q_{1}$ contains the effect of solar radiation and $Q_{2}$ the net flux of longwave radiation and sensible and latent heat per degree Celsius excess of $T_{S}$ over $T_{A}$. Expression (2.1) may equivalently be written in the form

$$
Q=Q_{2}\left(T_{A}^{*}-T_{S}\right),
$$

where $T_{A}^{*}=T_{A}+Q_{1} / Q_{2}$ is a kind of apparent atmospheric equilibrium temperature. It is larger than $T_{A}$ due to the effect of direct solar radiation, especially in the tropical ocean. The coupling factor $Q_{2}$ is not a constant in the scheme but varies with position and season; it is primarily a function of wind speed. Since both $T_{A}^{*}$ and $Q_{2}$ depend on atmospheric and radiation parameters only, they can, in principle, be computed using a set of climatological data. The prescribed functions $T_{A}^{*}$ and $Q_{2}$ for the thermal boundary condition used in the CME formulation of Bryan and Holland (1989) had been computed for each month based on various climatological datasets and empirical formulas as described by Han (1984). The same functions are taken for the present experiments.

Another factor determining the strength of the thermohaline overturning cell is given by the boundary conditions at the northern and southern edges of the model. As in the model of Sarmiento (1986), buffer zones are incorporated there in which potential temperature and salinity are restored to the monthly mean values as given by Levitus (1982). A number of sensitivity experiments have been performed that show the annual mean overturning and meridional heat transport critically depend on details of the boundary condition formulation (Holland and Bryan 1993; Döscher et al. 1993). As will be shown, however, the seasonal variation of heat transport in the model is largely a wind-driven effect; hence, the dependencies on the boundary conditions at the northern and southern walls need not be considered in the context of the present paper.

The main focus of the present study is provided by two of the IfM Kiel CME experiments, of five-year duration each, as described in Böning et al. (1991a):

Experiment 1 is forced with the monthly mean wind stresses of HR;

Experiment 2 is forced with the monthly mean wind stresses of Isemer and Hasse (1987; henceforth IH) north and HR south of the equator (with a transition zone between $0^{\circ}$ and $5^{\circ} \mathrm{N}$ ). 
In both cases, constant eddy coefficients for vertical viscosity $\left(10 \mathrm{~cm}^{2} \mathrm{~s}^{-1}\right)$ and diffusivity $\left(0.3 \mathrm{~cm}^{2} \mathrm{~s}^{-1}\right)$ and constant coefficients $\left(-2.5 \times 10^{19} \mathrm{~cm}^{4} \mathrm{~s}^{-1}\right)$ for the biharmonic lateral friction and diffusivity were used. To assess the influence of horizontal resolution on the seasonal variation of heat transport, the results of the $1 / 3^{\circ}$ models will be compared to coarse-resolution versions using a $1^{\circ} \times 1.2^{\circ}$ grid (experiments $1 \mathrm{C}$ and $2 \mathrm{C}$ ).

Experiment 3 in that sequence, with reduced coefficients for the biharmonic lateral friction, had relatively minor effects on volume transport and will not be considered here. However, we shall briefly mention another experiment that provides some useful complementary information. Whereas in the previous experiments a wind-forced deepening of the mixed-layer was not taken into account.

Experiment 4 included simple mixed-layer dynamics following the formulation of Camp and Elsberry (1978); all other model parameters are the same as in experiment 2.

The wind-induced turbulent kinetic energy available for entrainment at the base of the mixed layer $D_{m}$ is given by

$$
W=\alpha W_{A} e^{-D_{m} / D_{0}},
$$

where the atmospheric energy flux $W_{A}$ is taken from the computations of Hellerman and Rosenstein (1983) and the scale depth $D_{0}$ is taken as $50 \mathrm{~m}$. Several test runs have been made with different values for the parameter $\alpha$. The effect of the wind-induced mixing with $\alpha$ taken as 0.02 is illustrated in Fig. 3, which shows the annual cycle of potential temperature $\theta$ at a position in the subtropical gyre.

\section{Seasonal heat storage and surface fluxes}

The vertically integrated oceanic heat budget may be written as

$$
\begin{aligned}
Q=\int_{-D}^{0} \rho c_{p} \frac{\partial \theta}{\partial t} d z+\nabla_{h} \cdot & \int_{-D}^{0} \rho c_{p} \nu \theta d z \\
& +\int_{-D}^{0} \rho c_{p} A_{d} \nabla_{h}^{4} \theta d z,
\end{aligned}
$$

where $c_{p}$ is the specific heat at constant pressure, $\theta$ the potential temperature, and $A_{d}$ the coefficient for the biharmonic diffusion of heat in the model. The net surface flux of heat from the atmosphere to the ocean, $Q$, is balanced by the time rate of change of heat storage and the horizontal divergence of heat advection and diffusion in the ocean. Only the first two terms of (3.1) are directly accessible from available data; Lamb (1981), Lamb and Bunker (1982), and recently Hsiung et al. (1989) calculated the seasonal cycle of oceanic heat transport as a residual term. The prime difficulty of this indirect method lies in the near balance between the first two terms of (3.1) in midlatitudes: as suggested by theoretical considerations of seasonal variability (Gill and Niiler 1973) and demonstrated in observational studies (Hsiung et al. 1989), the seasonal variation of the net surface heat flux mainly affects the local storage of heat. Thus, the transport divergence in midlatitudes is a small residual of two large terms. That situation is in sharp contrast to the seasonal heat budget of the tropical oceans: there fast equatorial waves allow a baroclinic response to seasonal wind forcing; hence the seasonal variation of the surface currents is associated with large changes of heat content. As shown by Merle (1980), the seasonal heat storage in the equatorial Atlantic is governed mainly by the heat transport divergence.

The basic difference between tropical and extratropical regions had been demonstrated in the model study of $S$ and is also evident in the results of the present model. Figure 4 shows zonal averages of the surface heat flux and the annual march of heat content change integrated over the top $295 \mathrm{~m}$. The flux $Q$ is derived from the linear relation (2.2). Compared to $S$, who used a simplified version of that boundary condition with a constant coupling parameter $Q_{2}$ and sea surface temperatures as given by Levitus (1982) instead of the "apparent" atmospheric temperatures $T_{A}^{*}$ (which include the effect of direct solar radiation ), the formulation in the CME leads to a larger summer heat gain: in $\mathrm{S}$ it exceeded $100 \mathrm{~W} \mathrm{~m}^{-2}$ between $36^{\circ} \mathrm{N}$ and $50^{\circ} \mathrm{N}$; in the same latitude range, the CME model yields fluxes
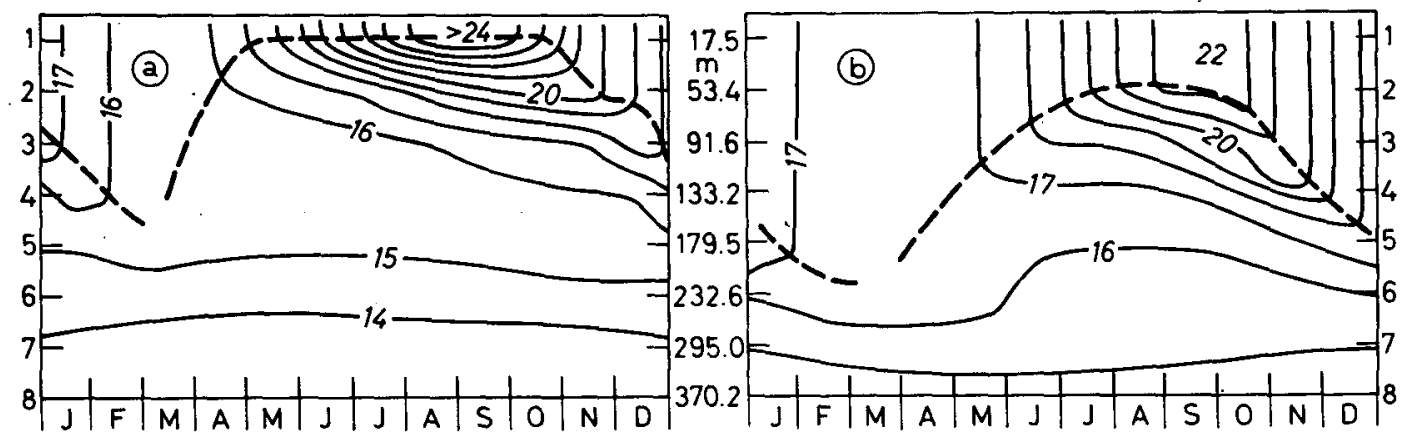

FIG. 3. Annual cycle of potential temperature $\left({ }^{\circ} \mathrm{C}\right.$ ) over the upper eight levels of the $\mathrm{CME}$ model, at $35^{\circ} \mathrm{N}, 30^{\circ} \mathrm{W}$ : (a) experiment 2 without wind-forced convection; (b) experiment 4 including the mixed-layer parameterization with $\alpha=0.02$. 

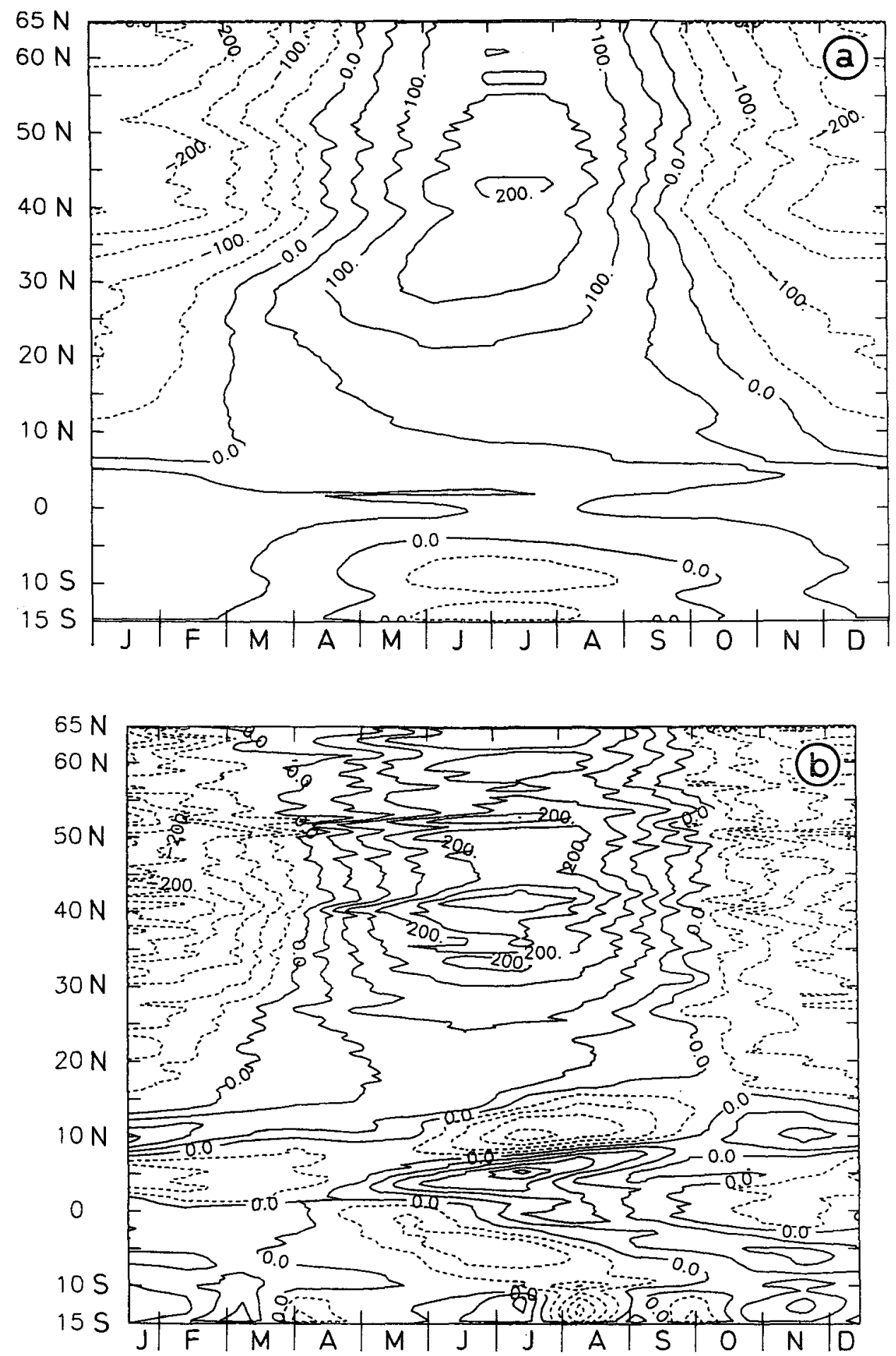

FIG. 4. Annual cycle of zonally averaged quantities in model experiment 4: (a) surface heat flux, (b) heat content change in the top $295 \mathrm{~m}$. The contour interval is $50 \mathrm{~W} \mathrm{~m}^{-2}$.

of more than $170 \mathrm{~W} \mathrm{~m}^{-2}$, with a maximum of 200 $\mathrm{W} \mathrm{m} \mathrm{m}^{-2}$ at $43^{\circ} \mathrm{N}$. The larger values seem to better capture recent observational estimates. Taking $25^{\circ} \mathrm{N}$ as an example, the model fluxes vary between -120 $\mathrm{W} \mathrm{m} \mathrm{m}^{-2}$ in December and $120 \mathrm{~W} \mathrm{~m}^{-2}$ in June. The heat loss in winter is similar as in Sarmiento's model, but 
in his case the summer heat gain was only about 50 $\mathrm{W} \mathrm{\textrm {m } ^ { - 2 }}$ at this latitude. The observational estimates of Isemer and Hasse (1987) and Hsiung et al. (1989) both indicate an annual range of about $250 \mathrm{~W} \mathrm{~m}^{-2}$ at $25^{\circ} \mathrm{N}$.

The annual march of surface heat flux in midlatitudes corresponds to the change of heat content shown in Fig. 4b. North of about $15^{\circ} \mathrm{N}$, heat is stored from April to September and released from October to March. Except for finer meridional scales, the model pattern is similar to results based on the climatological data of Levitus (1982) as shown by S (his Fig. 7b). As in these observational results, the model amplitude is largest at about $40^{\circ} \mathrm{N}$.

The seasonal heat budget is of a completely different nature in the equatorial Atlantic. South of $15^{\circ} \mathrm{N}$ the annual variation of surface heat flux is rather weak. The ocean gains heat throughout the year between $4^{\circ} \mathrm{S}$ and $7^{\circ} \mathrm{N}$ (Fig. 4a). Averaged over the year and across the basin the heat uptake at the equator is $75 \mathrm{~W} \mathrm{~m}^{-2}$ for experiments 1 and 2; maximum heat fluxes of more than $100 \mathrm{~W} \mathrm{~m}^{-2}$ are found between $20^{\circ}$ and $30^{\circ} \mathrm{W}$. In contrast to the surface flux, there is a strong variation in the heat content with opposite phases to the north and south of $8^{\circ} \mathrm{N}$ (Fig. 4b). Previous observational studies (Merle 1980; Garzoli and Katz 1983) and the model simulations of Philander and Pacanowski (1986a,b; hereafter PP) and S have shown that the seasonal variation in heat storage is associated with the vigorous circulation changes in the equatorial Atlantic. In boreal summer, when the North Equatorial Countercurrent (NECC) is most intense, the ocean gains heat to the south of $8^{\circ} \mathrm{N}$ where the thermocline deepens and releases heat to the north of $8^{\circ} \mathrm{N}$ where the thermocline shoals. The heat content between $8^{\circ}$ and $15^{\circ} \mathrm{N}$ is replenished in winter when the NECC and the associated thermocline slope disappear. Schott and Böning (1991) found the general features of the seasonal circulation changes in the present model to be similar as in the PP model but noted narrower current cores in the NECC region.

The meridional gradients in the pattern of heat storage change associated with the variation of the NECC are captured to a much lesser degree in observational studies relying on smoothed datasets; for example, there is only a weak indication of a corresponding heating/cooling pattern in the analysis of Hsiung et al. (1989), probably due to their averaging over $5^{\circ}$ latitude belts. As will be shown in section 4 , the opposite heating/cooling cycles to the south and north of $8^{\circ} \mathrm{N}$ are associated with a large annual variation of meridional heat transport across this latitude belt.

In Fig. 5 the annual cycle of surface heat flux is compared to the heat content change at four selected latitudes. The curves clearly demonstrate the different nature of the seasonal heat budget in the equatorial regime compared to the higher latitudes. In the subtropical
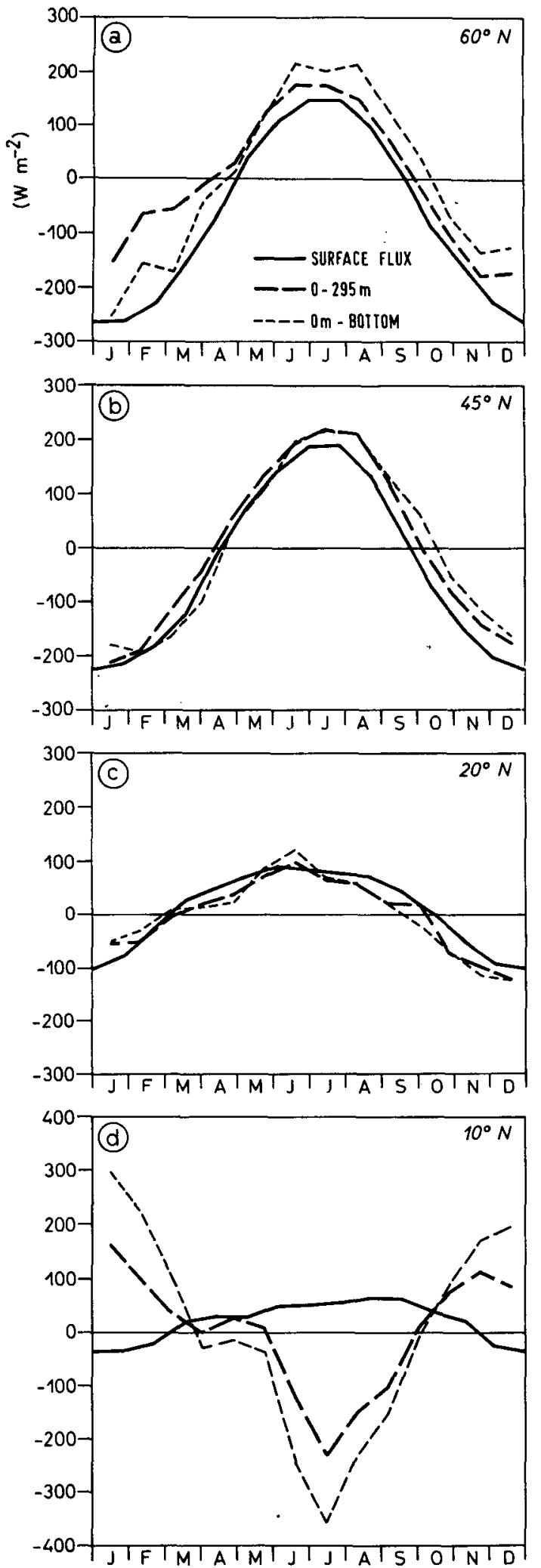

FIG. 5. Annual cycle at selected latitudes of experiment 4: zonally averaged surface heat flux and heat content change, calculated over the whole water depth $(0 \mathrm{~m}$-bottom) and over the top $295 \mathrm{~m}(0-$ $295 \mathrm{~m}$ ). 
$\left(20^{\circ} \mathrm{N}\right)$, midlatitude $\left(45^{\circ} \mathrm{N}\right)$, and subpolar North Atlantic $\left(60^{\circ} \mathrm{N}\right)$ the variation in heat content is largely explained by the surface flux. The heat transport divergence is obviously of minor importance for the seasonal heat budget in these regions. The seasonal variation of heat storage is shown for two different depth ranges: calculated over the whole water column, and the top $295 \mathrm{~m}$ only (i.e., the same as in Fig. 4). Due to the sparsity of deeper ocean data, observational studies have usually relied on data from a similar depth range; for example, Hsiung et al. (1989) limited their calculations to $300 \mathrm{~m}$. The analysis of Levitus (1984) had indicated only little differences between heat storage cycles integrated through depths $275 \mathrm{~m}$ and 550 $m$ in the Northern Hemisphere midlatitudes. However, his $550-\mathrm{m}$ heat storage exhibited larger magnitudes compared to the $275-\mathrm{m}$ values in the equatorial ocean $\left(12^{\circ} \mathrm{N}\right.$ ). The model results (Fig. 5) show a similar behavior. In the subtropical $\left(20^{\circ} \mathrm{N}\right)$ and midlatitude $\left(45^{\circ} \mathrm{N}\right)$ North Atlantic the heat content changes in the top $295 \mathrm{~m}$ resemble most of the total change. This is not the case in higher latitudes where wintertime convection reaches to greater depth, and also not in the equatorial Atlantic; apparently, the heat content changes associated with displacements of the tropical thermocline are not fully captured in the $295-\mathrm{m}$ integrals.

A comparison of the simulated heat content changes with climatological data from the midlatitude North Atlantic is offered in Fig. 6. It had been suggested by $S$ that the summer heat gain in model simulations without vertical mixing by wind-forced convection could be too small. However, as noted above, the present model yields much larger summer fluxes even without wind-forced mixing, due to the different boundary condition that includes the effect of solar radiation. As shown by Fig. 6 , the addition of the mixed-layer scheme in experiment 4 leads only to a slightly enhanced variation of heat content in the model. Without wind-forced convection (experiments 1 and 2) the depth of the mixed layer during the heating season is given by the first model level; in experiment 4 typical mixed-layer depths in midlatitudes are about $50 \mathrm{~m}$ (Fig. 3). Both model cases show a reasonable simulation of the observed changes. While at $20^{\circ} \mathrm{N}$ the mixed-layer model seems to improve the simulation, the reverse seems to be the case at $45^{\circ} \mathrm{N}$. A detailed quantitative validation of the heat content change in the model appears difficult given the considerable differences between various observational studies, using different oceanic datasets.

\section{Seasonal heat transport and meridional overturning}

The annual cycle in the northward transport of heat $H$ through zonal cross sections of the ocean basin as a function of latitude for case 1 (HR forcing) and case
2 (IH forcing) is shown in Fig. 7. The pattern in both experiments is similar to the result of $\mathrm{S}$ obtained with a $2^{\circ} \times 2^{\circ}$ model and HR forcing. The equatorial Atlantic is characterized by seasonal heat transports from the summer to the winter hemisphere, the amplitude of the annual variation being largest at about $8^{\circ} \mathrm{N}$. In midlatitudes, maximum northward transports occur in summer. In the transition zone between the two regimes from about $12^{\circ}$ to $25^{\circ} \mathrm{N}$ there is a semiannual variation with transport maxima both in winter and summer.

As had been noted in previous analyses of CME results (Bryan and Holland 1989; Böning et al. 1991a), the annual mean northward transport of heat is too weak compared to observational estimates: the maximum transports of the various high-resolution runs are between 0.65 and $0.75 \mathrm{PW}$, in the latitude range of $30^{\circ}-35^{\circ} \mathrm{N}$. The main reason for this model deficiency appears to be an unsatisfactory simulation of the production and southward transport of lower North Atlantic Deep Water, resulting in a maximum overturning in the latitude-depth plane of only $12 \mathrm{~Sv}\left(\mathrm{~Sv} \equiv 10^{6}\right.$ $\mathrm{m}^{3} \mathrm{~s}^{-1}$ ). Various sensitivity experiments have been performed that demonstrate the important role of the boundary conditions at the artificial walls in the north and south on the strength of the thermohaline circulation. An analysis of the mean heat transport and its sensitivity to various model factors will be presented separately. As will become clear in the following discussion, seasonal (and shorter period) variations in meridional heat transport can be understood largely as a wind-driven effect.

In Fig. 8 particular aspects of the seasonal variation of $H$ are emphasized to allow an easier comparison with the observational and model results presented in Fig. 1. The latitudinal dependence of heat transport during January and July (Figs. 8a-c) is in qualitative correspondence to previous model solutions. However, the amplitude of the annual variation is larger than in some of the earlier studies and indicates a dependency on wind stress climatology and grid resolution (Table 1). The maximum annual range is found in the tropical Atlantic near $8^{\circ} \mathrm{N}$, corresponding to the large changes in heat content to the north and south of that latitude associated with the seasonal variation of the NECC (Fig. 4b). In experiment 1 , the difference between the winter maximum and summer minimum of northward heat transport is very similar to the result obtained by PP using the same latitudinal grid spacing $\left(1 / 3^{\circ}\right)$ in the equatorial Atlantic and the same wind stresses ( $H R$ ). That annual range, roughly $2 \mathrm{PW}$, is significantly larger than the range of about $1.4 \mathrm{PW}$ obtained by $\mathrm{S}$ with a $2^{\circ}$ model, also forced with the HR stresses. The sensitivity to horizontal resolution in the NECC regime is demonstrated also by the coarser grid $\left(1^{\circ}\right)$ version of the CME model (experiment $1 \mathrm{C}$ ), yielding an annual range of $1.7 \mathrm{PW}$ at $8^{\circ} \mathrm{N}$. With $\mathrm{IH}$ forcing the annual range at that latitude increases to nearly $2.5 \mathrm{PW}$ in the 

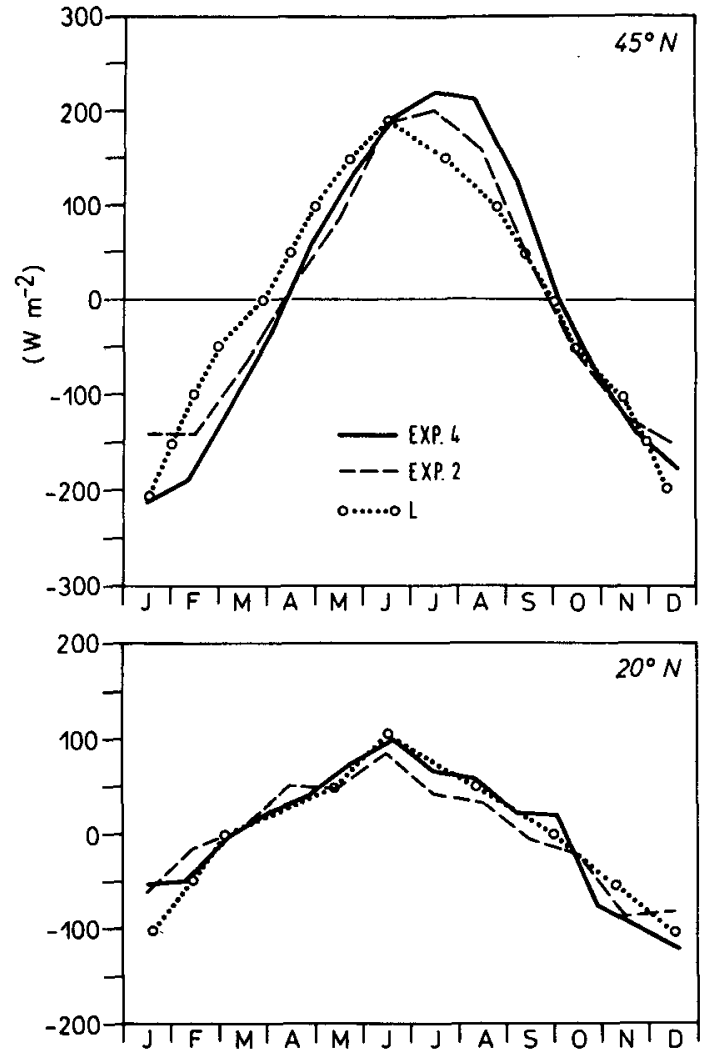

FIG. 6. Annual cycle of zonally averaged heat content change (0$295 \mathrm{~m}$ ) at $20^{\circ}$ and $45^{\circ} \mathrm{N}$, compared to the climatology of Levitus (1982) (from Sarmiento 1986, Fig. 7b): model experiment 2 without and experiment 4 with wind-forced mixing.

$1 / 3^{\circ}$ case and 2.2 PW in the $1^{\circ}$ case (experiment $2 \mathrm{C}$ ). In the subtropics, the annual variation of heat transport seems to be much less sensitive to horizontal resolution. The annual range of the $1 / 3^{\circ} \mathrm{CME}$ model with $\mathrm{HR}$ forcing (experiment 1 ) is about $0.5 \mathrm{PW}$, similar to the result of the $1^{\circ}$ version of that model and not much different from Sarmiento's $2^{\circ}$ model results. The difference between the summer maximum and winter minimum of northward heat transport is substantially enhanced with IH forcing (experiment 2), whereby the latitude of maximum annual variation moves southward from $34^{\circ}(\mathrm{HR})$ to $27^{\circ} \mathrm{N}(\mathrm{IH})$. The incorporation of wind-forced convection (experiment 4 ) has little influence on the seasonal heat transports in the tropics and is negligible in higher latitudes.

Some insight into the mechanism of the seasonal variation may be gained by considering the different components of heat transport obtained by a formal decomposition. First, it should be noted that the diffusive heat transport is very small in the present highresolution model, that is, less than $0.01 \mathrm{PW}$ at all latitudes. In good approximation, the meridional heat transport is given by advection alone and may be written as

$$
H=\rho_{0} c_{p}\{v \theta\},
$$

where \{\} denotes an area integration over a zonal cross section of the ocean basin for which there is no net volume transport, that is, $\{v\}=0$. Let angle brackets denote a zonal average over the width of the section. Writing the variables as

$$
v=\langle v\rangle+v^{*}, \quad \theta=\langle\theta\rangle+\theta^{*},
$$

the total heat transport at any latitude may be decomposed as

$$
H=\rho_{0} c_{p}\left\{\langle v\rangle\langle\theta\rangle+\left\langle v^{*} \theta^{*}\right\rangle\right\} .
$$

The first term on the right-hand side represents the effect of overturning in the latitude-depth plane and will be denoted by $H_{\mathrm{OT}}$; the second term represents the effect of correlations in the horizontal plane and
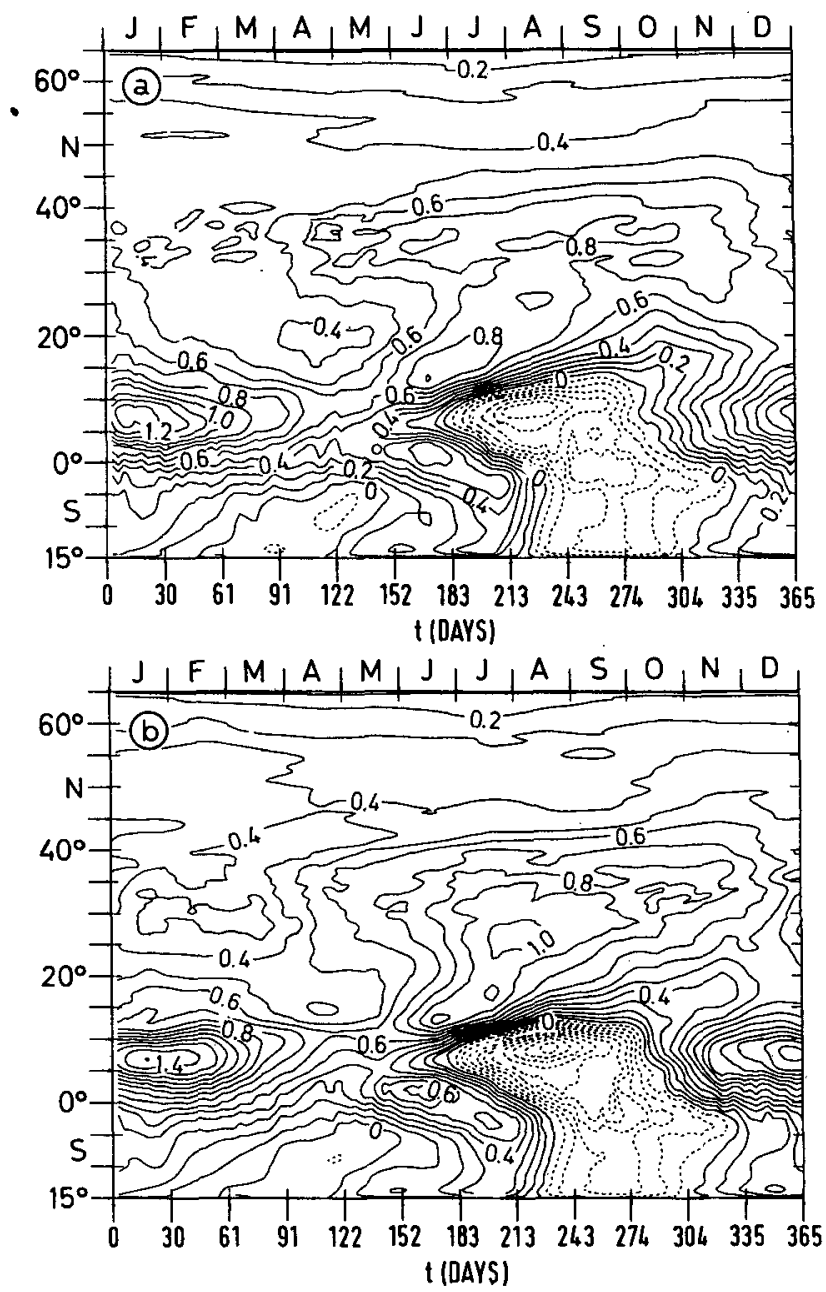

FIG. 7. Northward heat transport as function of time in petawatts, averaged over five years (a) of model experiment 1 (HR) and (b) experiment $2(\mathrm{IH})$. Contour interval is $0.1 \mathrm{PW}$; negative contours are dashed. 

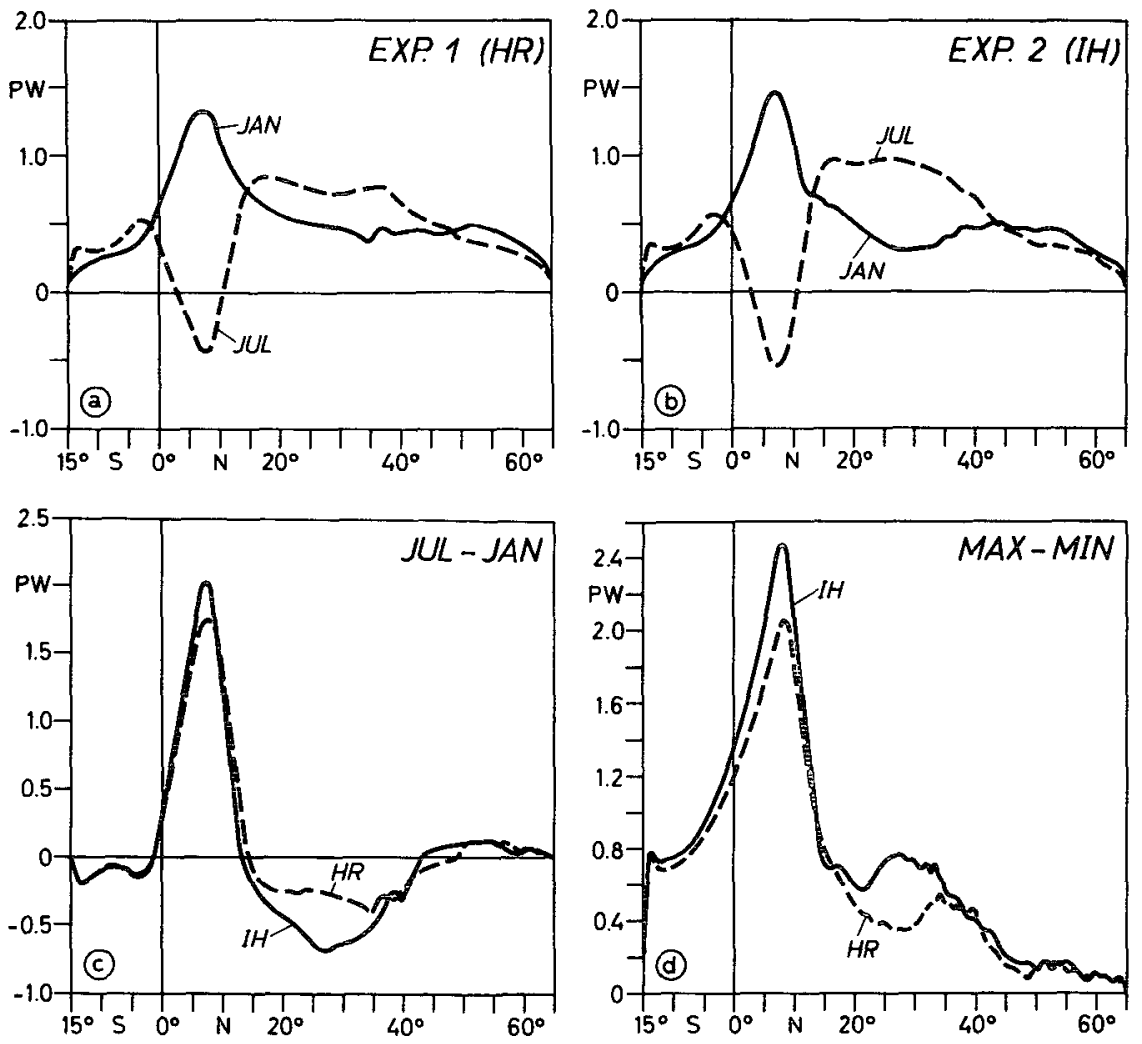

FIG. 8. (a) Northward heat transport as function of latitude in January and July, averaged over five years of experiment 1 (HR) and (b) of experiment 2 (IH). (c) Difference between heat transport in January and July of experiments 1 and 2 , and (d) the annual range, defined as the difference between the maximum and minimum northward heat transports for each latitude.

may be understood as the effect of oceanic gyres; we will refer to it as $H_{\mathrm{GY}}$.

Figure 9 shows the annual cycle of $H, H_{\mathrm{OT}}$, and $H_{\mathrm{GY}}$ for several latitudes. Almost everywhere the variation of $H$ is governed by the variation of the overturning component $H_{\mathrm{Or}}$; neither in the tropics nor in the subtropics is there a significant contribution by $H_{\mathrm{GY}}$; at $25^{\circ} \mathrm{N}$ the annual range of $H_{\mathrm{GY}}$ is less than $0.1 \mathrm{PW}$, and at $8^{\circ} \mathrm{N}$ less than $0.2 \mathrm{PW}$. Further analysis of the physical mechanism and cause of the seasonal variation in $H$ can be based therefore on an examination of the variation in meridional overturning.

The pattern of the transport streamfunction for the zonally averaged flow is very similar for experiments 1 and 2 (Fig. 10). The main difference is the strength of the shallow wind-driven cells near the surface; the stronger zonal wind stresses of the IH climatology (Böning et al. 1991b) cause an enhanced equatorial upwelling and subtropical convergence. The stronger wind-driven cell in the subpolar Atlantic of experiment 2 may explain the slight reduction of the deep overturning cell associated with the formation of North Atlantic Deep Water (NADW) in that experiment; the transport maximum near $50^{\circ} \mathrm{N}$ is $12.2 \mathrm{~Sv}$ for $\mathrm{HR}$ and $11.9 \mathrm{~Sv}$ for $\mathrm{IH}$ forcing. The NADW cell reaches only to about 2500-m depth; below that the model produces a prominent counterrotating cell associated with northward transport of Antarctic Bottom Water (AABW). As noted above, the mean overturning pattern strongly depends on the boundary conditions at the northern and southern walls; these dependencies will not be investigated here.

The January and July distributions of the meridional transport streamfunction are displayed in Figs. 11a,b. There is almost no difference in the deep sinking north of $50^{\circ} \mathrm{N}$. As shown by the sensitivity experiments of Döscher et al. (1993), the deep circulation responds to changes in the thermohaline boundary conditions on time scales of a few years. Therefore, the annual cycle of heating and cooling cannot exert a significant influence on the meridional overturning. Instead, the patterns reveal a strong seasonal variation in the meridional overturning farther south. The structure of these seasonal circulation changes is elucidated in Figs. $11 \mathrm{c}$,d, which show the January minus July differences of the transport streamfunctions. The experiments show two deep seasonal overturning cells, corresponding to a northward transport anomaly at the surface of the tropical Atlantic and a southward transport anomaly at the surface in midlatitudes. Similar, albeit weaker, 
TABLE 1. Annual range of northward heat transport (in PW) in models of the Atlantic Ocean, forced with the monthly mean wind stresses of Hellerman-Rosenstein (HR) or Isemer-Hasse (IH).

\begin{tabular}{|c|c|c|c|c|c|}
\hline & \multirow{2}{*}{$\begin{array}{l}\text { Horizontal grid } \\
\text { (lat } \times \text { long) }\end{array}$} & \multirow{2}{*}{$\begin{array}{l}\text { Vertical } \\
\text { levels }\end{array}$} & \multirow{2}{*}{$\begin{array}{l}\text { Wind } \\
\text { stress }\end{array}$} & \multicolumn{2}{|c|}{ Annual range (PW) } \\
\hline & & & & Equatorial & Subtropical \\
\hline Sarmiento (1986) (S) & $2^{\circ} \times 2^{\circ}$ & 25 & HR & $\sim 1.4$ & $\sim 0.4$ \\
\hline Philander and Pacanowski (1986b) (PP) & $1 / 3^{\circ} \times 1^{\circ}$ & 27 & HR & 1.95 & - \\
\hline \multicolumn{6}{|l|}{ Present experiments (CME) } \\
\hline 1 & $1 / 3^{\circ} \times 0.4^{\circ}$ & 30 & HR & 2.06 & 0.53 \\
\hline 2 & $1 / 3^{\circ} \times 0.4^{\circ}$ & 30 & $\mathrm{IH}$ & 2.48 & 0.77 \\
\hline 4 & $1 / 3^{\circ} \times 0.4^{\circ}$ & 30 & $\mathrm{IH}$ & 2.30 & 0.77 \\
\hline ic & $1^{\circ} \times 1.2^{\circ}$ & 30 & HR & 1.70 & 0.50 \\
\hline $2 \mathrm{C}$ & $1^{\circ} \times 1.2^{\circ}$ & 30 & $\mathrm{IH}$ & 2.23 & 0.72 \\
\hline
\end{tabular}

seasonal cells had been noted by Bryan (1982) in his analysis of the $\mathrm{BL}$ model. In that coarse-resolution model the tropical anomaly was more symmetrical about the equator whereas in the present case it has its maximum between $5^{\circ}$ and $10^{\circ} \mathrm{N}$. Forcing the model with IH instead of HR increases the strength of the cells. A second effect of the different wind stresses may be seen in the position of the subtropical maximum; with IH stresses it shifts to the south and the seasonal variation becomes much stronger between about $15^{\circ}$ and $25^{\circ}$ N. As had been shown above (Fig. 9), the seasonal heat transport changes are caused primarily by the circulation in the meridional-vertical plane. Accordingly, a comparison between Fig. $8 \mathrm{c}$ and Figs. $11 \mathrm{c}, \mathrm{d}$ indicates strong similarities between the latitudinal patterns of seasonal overturning and meridional heat transport.

Some relevant features of the monthly mean zonal wind stresses of HR and IH causing the seasonal changes in meridional circulation are illustrated in Fig. 12. The seasonal variation of the westerlies centered at about $50^{\circ} \mathrm{N}$ is somewhat stronger in the climatology of HR. More important for the ocean's response is the seasonal variation of the stress at lower latitudes. The annual amplitude seems to be small near the peak of the trades at $15^{\circ} \mathrm{N}$ (however, there is a semiannual component at this latitude; see the following). The latitude of the trade wind maximum separates two different regimes of seasonal variation. The variation to the north can be understood as a consequence of the meridional shift of the Azores high; its northward migration from winter to summer, reflected in the latitude of vanishing zonal wind stress (Figs. 12a,b), is associated with increasing westward stresses in the subtropics. It should be noted that the seasonal variation in the latitude range from $15^{\circ}$ to $35^{\circ} \mathrm{N}$ is much stronger in the IH stresses (Fig. 12c). The behavior to the south of the trade wind maximum is governed by the seasonality of the intertropical convergence zone (ITCZ), which leads to smaller westward stresses between $2^{\circ}$ and $15^{\circ} \mathrm{N}$ in summer. As the phase of the northward migration of the ITCZ is different from that of the Azores high-the former occurs rather abruptly during
June/July - there is a tendency toward a semiannual variation of the meridional pressure gradient between about $10^{\circ}$ and $20^{\circ} \mathrm{N}$ (e.g., see Böning et al. $1991 \mathrm{~b}$, their Figs. 4 and 5). In this transition zone, relative maxima of the westward trades occur in January and June.

The opposite seasonal cycles of the zonal wind stress in the tropics and subtropics are reflected in the winddriven meridional volume transport in the surface layer of the ocean. The Ekman transport, integrated across the width of the ocean basin $L$, is given by

$$
T_{\mathrm{Ek}}=-\int_{0}^{L}\left(\tau^{(x)} / f\right) d x
$$

The January - July difference of the transport density, that is, the zonal average of the argument $-\tau^{(x)} / f$, is shown in Fig. 12d. (A value of $10^{4}$ dyn s cm$~_{-1}=10^{3}$ $\mathrm{Pa} \mathrm{s}^{-1}$ translates to a zonally integrated Ekman transport of $6 \times 10^{6} \mathrm{~m}^{3} \mathrm{~s}^{-1}$ in a basin of width $6000 \mathrm{~km}$.) The combined northward transport anomaly in the trade wind regime and the southward transport anomaly in the midlatitudes lead to an enhanced subtropical convergence in winter. Again, the meridional patterns of the seasonal transport changes are different for the HR and IH stresses; in the subtropical North Atlantic, the annual amplitude inferred from $\mathrm{IH}$ is more than twice the amplitude from HR. A comparison between Figs. $11 \mathrm{c}, \mathrm{d}$ and Fig. $12 \mathrm{~d}$ reveals a striking similarity in the latitudinal pattern of the simulated volume transport changes at the surface and the meridional Ekman transport anomalies. This gives a first indication that the seasonal overturning cells represent the model's response to the zonal wind stress variations.

An important feature of the model is that the depth distribution of the compensatory flows to the seasonal surface transport anomalies (Figs. 11c,d) is very different from the annual mean pattern as shown in Fig. 10. The response to the seasonal transport changes at the surface seems to be approximately depth independent; except for a narrow regime near the equator, there is no indication of a baroclinic compensation that in the annual mean case causes the wind-driven flow to 

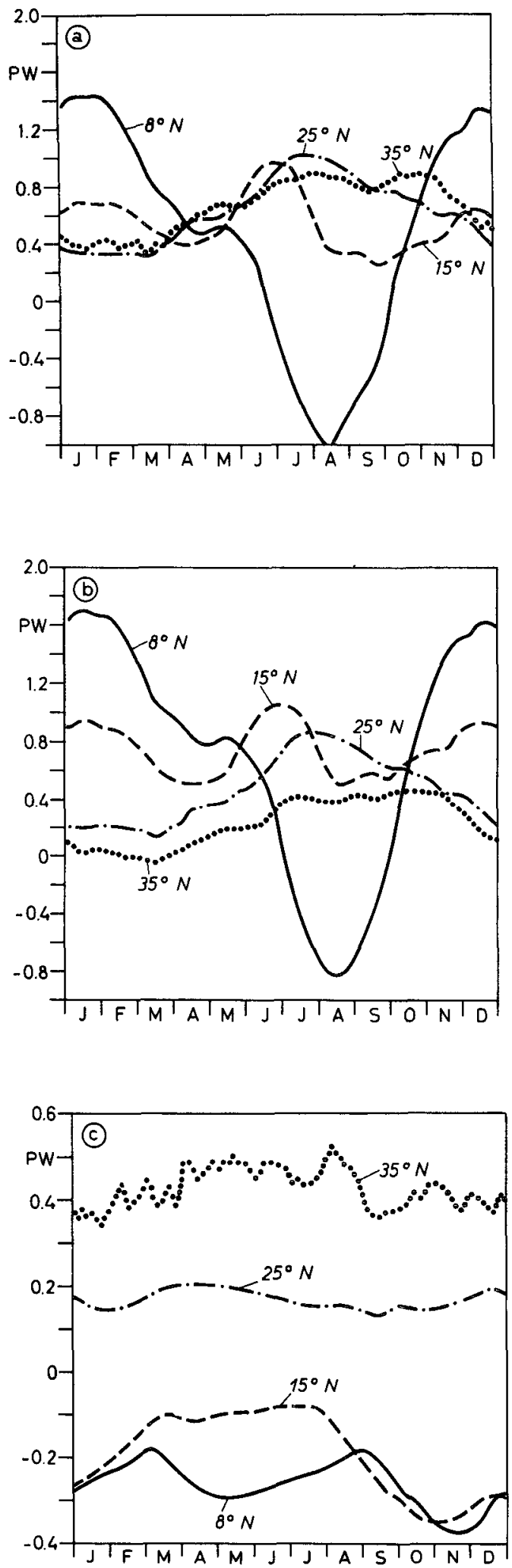

FIG. 9. Mean annual cycle at selected latitudes of (a) total northward heat transport $H$, and the contributions (b) from meridional overturning $H_{\mathrm{OT}}$, and (c) horizontal gyre $H_{\mathrm{GY}}$; experiment 2 . be confined to the upper few hundred meters. The effect of the Ekman transport changes for the seasonal variation of northward heat transport $\left(H_{\mathrm{Ek}}\right)$ can be calculated only if there is information about the temperature difference between the wind-driven transport at the surface and the compensatory flow at depth. An assumption has often been made that the deep return flow associated with the Ekman transport at the surface takes place with the depth-averaged potential temperature $[\theta]$; hence,

$$
H_{\mathrm{Ek}}=\rho_{0} c_{p} \int_{0}^{L}\left(-\frac{\tau^{(x)}}{f}\right)\left(\theta_{s}-[\theta]\right) d x
$$

where $\theta_{s}$ either represents the surface temperature (e.g., Kraus and Levitus 1986) or is taken as a weighted average of the temperatures in the mixed layer (e.g., Hall and Bryden 1982; Bryden et al. 1991). Lacking direct measurements, the applicability of (4.5) to the calculation of seasonal changes in meridional heat transport is controversial. While Kraus and Levitus (1986), in using (4.5), implicitly assumed a deep compensatory flow, Bryden et al. (1991) assumed that there is only little seasonal variation in the deep ocean (below 700 $\mathrm{m})$. Therefore, with a much smaller temperature difference than in (4.5), they predicted much lower values for the annual amplitude of heat transport in the subtropical ocean than Kraus and Levitus (1986) had calculated on the basis of (4.5).

In contrast to observations, model results allow an examination of the question to which extent (4.5) represents a good approximation to the effect of seasonal Ekman transport changes on meridional heat transport. Since the annual range of $H_{\mathrm{GY}}$ is small (Fig. 9), the variation of $H_{\mathrm{OT}}$ approximately represents the variation of total heat transport $H$. Figure 13 demonstrates that the annual cycle in the overturning component $H_{\mathrm{OT}}$ is quite well approximated by the calculation of $H_{\mathrm{Ek}}$ based on (4.5). This again suggests that the seasonal overturning cells seen in Figs. 11c,d can be understood as an effect of the Ekman transport changes at the surface. The variation of $H_{\mathrm{Ek}}$ somewhat underrepresents the annual range of $H_{\mathrm{OT}}$, indicating that the mean temperature of the deep return flow may be actually lower than the depth-averaged temperature $[\theta]$. Given the rapid decrease of temperature over the thermocline, such an effect would have to be expected in the case of an approximately depth-independent return flow.

Though the zonally integrated pattern of the windinduced transport anomalies looks very simple (Figs. $1 \mathrm{lc}, \mathrm{d})$, it in fact conceals the rather complicated longitudinal distribution of the meridional velocity anomalies across the ocean basin (Fig. 14a). The heat transport analysis in terms of zonally integrated quantities lumps together local and nonlocal effects in the ocean's response to the seasonal wind forcing. In addition to the Ekman drift currents there is also a response of the oceanic gyres to variations in the wind 

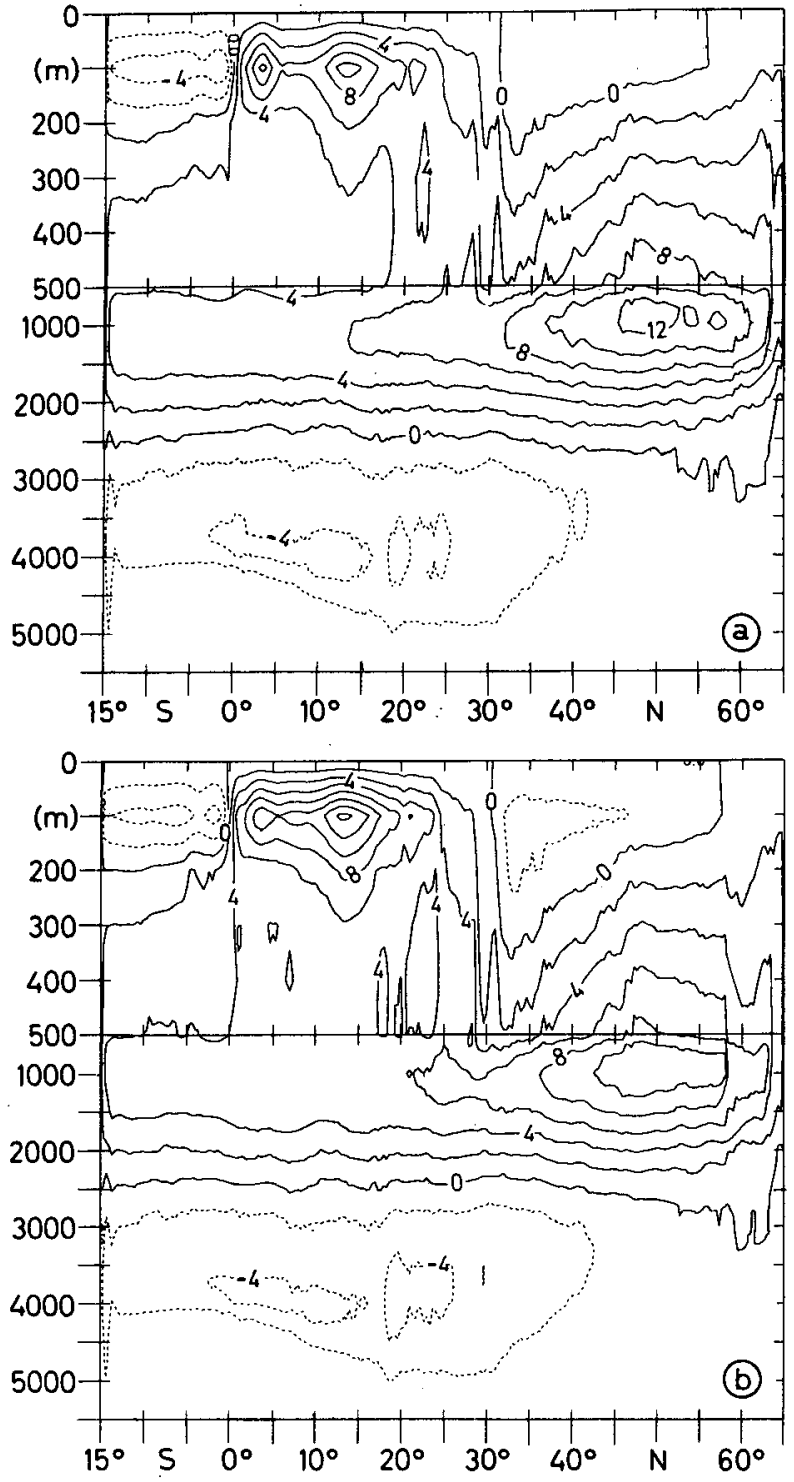

FIG. 10. Annual mean streamfunction of zonally integrated volume transport in the meridional-depth plane for (a) experiment 1 and (b) experiment 2 . The contour interval is $2 \times 10^{6} \mathrm{~m}^{3} \mathrm{~s}^{-1}$.

stress curl. Theory (Gill and Niiler 1973) and model studies (Anderson et al. 1979) suggested that except for a narrow equatorial belt the seasonal response to large-scale forcing is primarily barotropic; baroclinic Rossby waves have only little effect on transport variations unless forcing adjacent to the western boundary is considered. As was first indicated in an idealized model study of Anderson and Corry (1985), the barotropic signal in the subtropical North Atlantic should be blocked by the topography of the Bahamian archipelago. In the present model, a large annual signal in boundary current transport was found to the east of the Bahamas, decoupled from the smaller and locally forced variation in the Florida Straits (Böning et al. 1991a). A corresponding, large signal in meridional velocity at the continental slope is evident in Fig. 14a. Somewhat enhanced deep velocity variations also occur over the eastern flank of the Mid-Atlantic Ridge, which acts as barrier for barotropic Rossby waves carrying the wind-induced signal from the eastern basin westward. With the exception of these regions with steep bottom slopes, the seasonal velocity signal in the deep ocean interior is very weak, on the order of a millimeters per second.

The volume transport anomalies through various portions of the cross section at $25^{\circ} \mathrm{N}$ are shown in Fig. $14 \mathrm{~b}$. Integrated zonally across the basin, the difference in Ekman transport between the two seasons is roughly 4 Sv, consistent with the overturning anomaly of Fig. $11 \mathrm{c}$. While the wind-driven flow in the surface layer is distributed rather uniformly across the basin, the deep ocean return flow is not. The subsurface transport pattern is dominated by the variation of the subtropical gyre. The gyre transport in the winter quarter exceeds the summer value by $13 \mathrm{~Sv}$. The model analysis of Böning et al. (1991a) showed a seasonal variation of the western boundary current approximately following the wind stress curl over the western half of the basin, with a maximum in January and minimum in October, and an annual range of about $25 \mathrm{~Sv}$. The phase of the Florida Current variation, which follows the local wind stress, is different, with a maximum in summer and a minimum in fall; the annual range is about $6 \mathrm{~Sv}$ with IH forcing. The difference between the summer and winter quarter as defined in Fig. 14 is only $0.8 \mathrm{~Sv}$. The important point to be made here is that despite the strong variation in gyre transport it has a negligible effect on the seasonal cycle of heat transport in the model (Fig. 9). The annual signal in $H$ is due to the comparatively small variation in Ekman transport and its associated deep return flow that, according to Fig. $14 \mathrm{~b}$, is concentrated at the western boundary.

A corresponding calculation of summer minus winter transport differences is given in Fig. $14 \mathrm{c}$ for the cross section at $8^{\circ} \mathrm{N}$. Vertical overturning associated with the Ekman transport signal is stronger here and comparable in magnitude to the variation in gyre transport. The surface transport anomaly is compensated to a larger degree in the top $1500 \mathrm{~m}$ than it is the case in the subtropics, indicating a stronger baroclinic nature of the seasonal response. The vertically integrated transport shows an enhanced cyclonic gyre during summer (by $16 \mathrm{~Sv}$ ), corresponding to the summer maximum of the NECC, which is partially fed by southeastward flow along the western boundary; the model analysis of Schott and Böning (1991) showed 10.3 Sv feeding into the NECC, mostly of NEC water, from west of $53^{\circ} \mathrm{W}$ in August, compared to northwestward transport of $4.5 \mathrm{~Sv}$ across that longitude in February. The semiannual variation of $H_{G Y}$ at $8^{\circ} \mathrm{N}$ (Fig. 9) cannot easily be related to the NECC cycle. On the other hand, the contribution to the heat trans- 

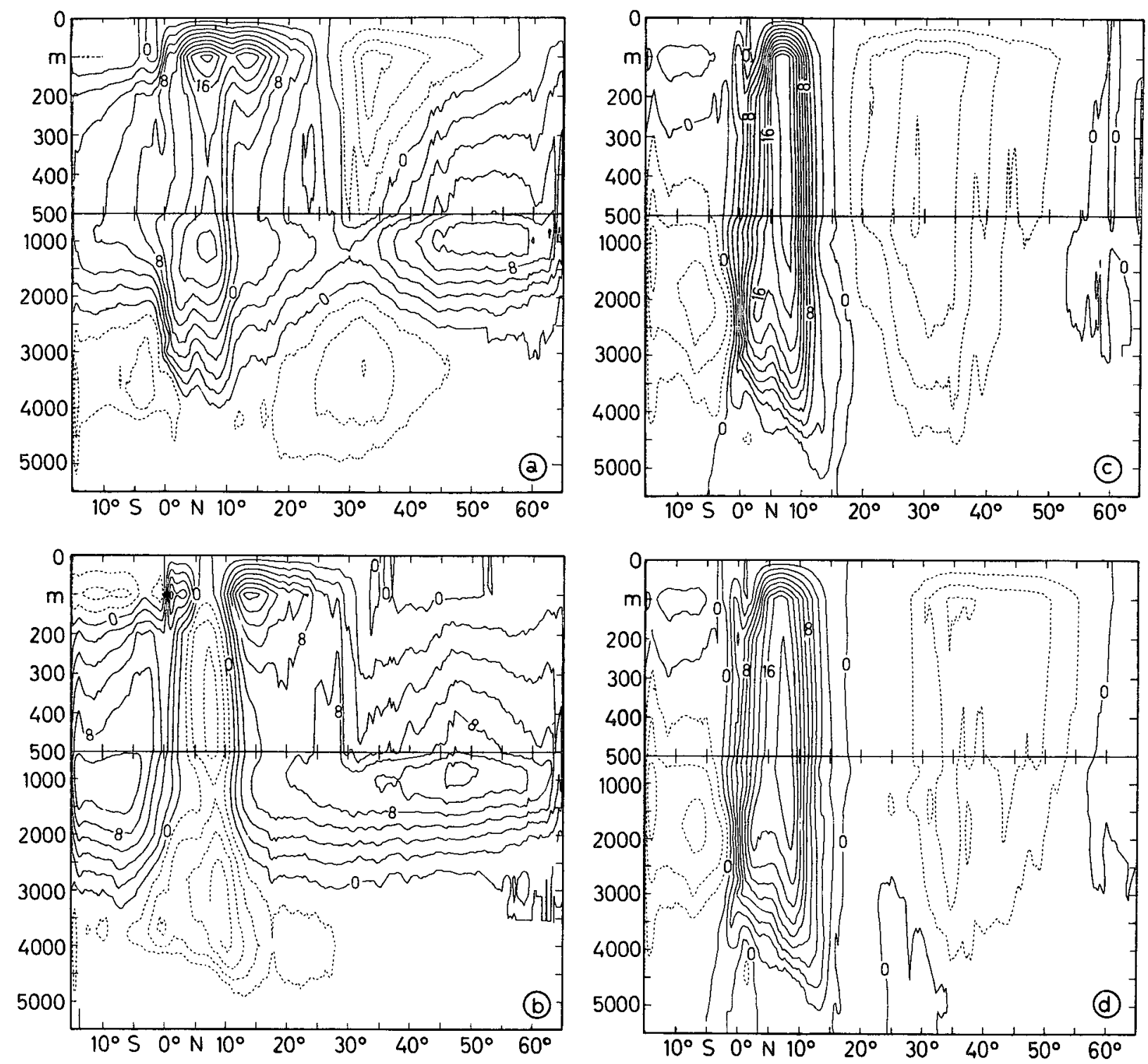

FIG. 11. (a) January and (b) July pattern of zonally integrated transport for experiment 2. (c) Difference between January and July transport for experiment 2 and (d) for experiment 1 . The contour interval is $2 \times 10^{6} \mathrm{~m}^{3} \mathrm{~s}^{-1}$.

port by the gyre signal, which has an annual range of less than $0.2 \mathrm{PW}$ (Fig. 9), is very small.

\section{Summary and discussion}

The basic characteristics of the annual cycle in meridional heat transport found in the CME simulations are the same as in previous model studies: the northward heat transport has a winter maximum in the equatorial Atlantic and a summer maximum in the subtropics. The nature of the seasonal heat budget is quite different in these two regimes. In the equatorial Atlantic, the variation of the surface fluxes is weak and the transport divergence is balanced primarily by the change in heat content. During the northern summer, the thermocline deepens and heat is gained south of $8^{\circ} \mathrm{N}$, and the thermocline rises and heat is lost between $8^{\circ}$ and $15^{\circ} \mathrm{N}$. The amplitude of the annual variation in heat transport across $8^{\circ} \mathrm{N}$ associated with the meridional gradient in the heat storage cycle in that regime is strongly dependent on the model resolution, which affects the representation of the NECC (Schott and Böning 1991). The CME model with HR forcing gives approximately the same annual variation at $8^{\circ} \mathrm{N}$ as the model of PP, using the same meridional grid spacing $\left(1 / 3^{\circ}\right)$ in the equatorial Atlantic. The annual range is significantly larger than in models with coarser grids (Table 1). North of about $15^{\circ} \mathrm{N}$, seasonal changes in 

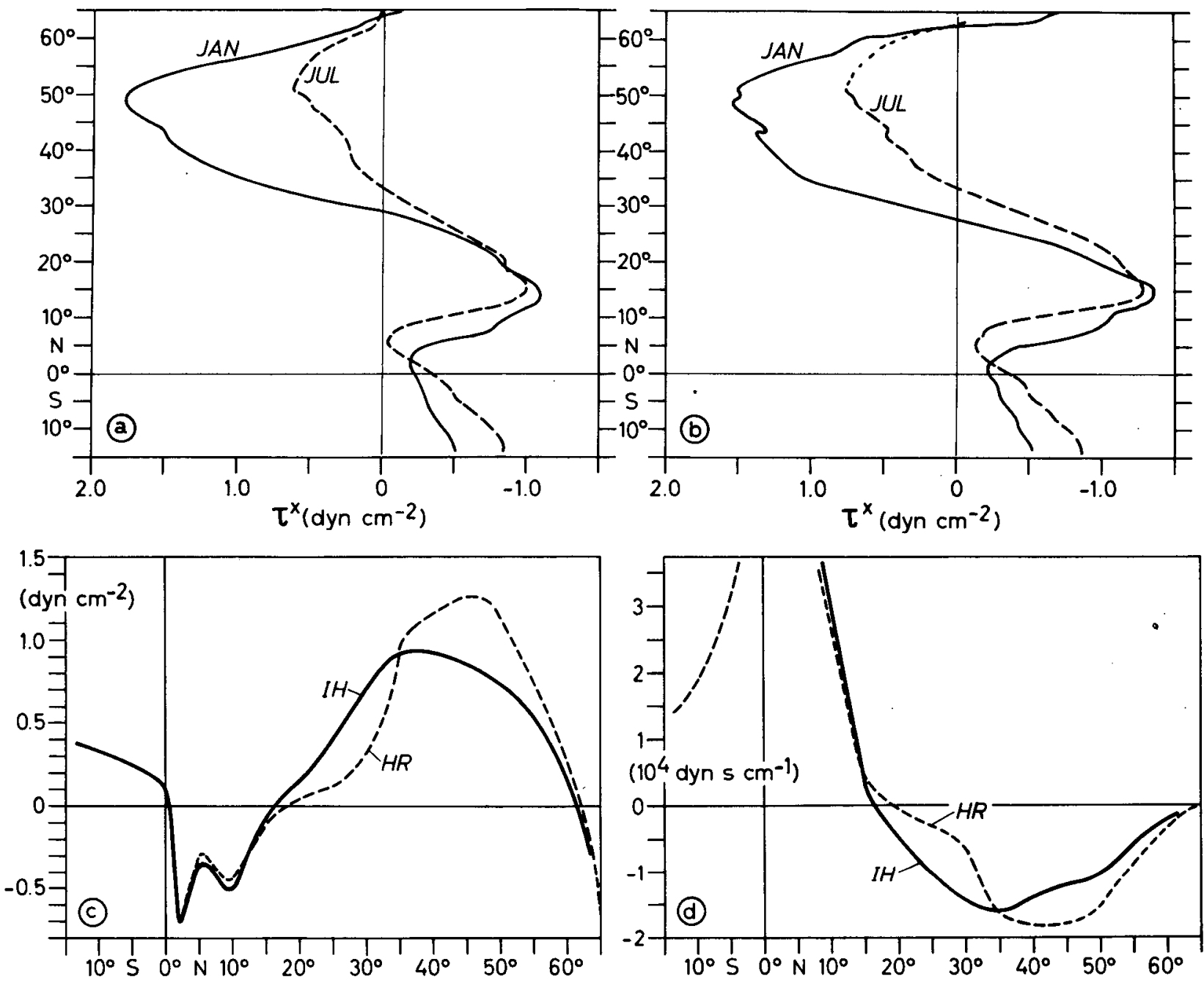

FIG. 12. (a) Zonal wind stress $\tau^{(x)}$ in January and July according to HR, and (b) IH (in the modified version used in the model, i.e., HR south of the equator, and smooth transition from HR to IH between $0^{\circ}$ and $5^{\circ} \mathrm{N}$ ); (c) January-July difference in $\tau^{(x)}$, and (d) JanuaryJuly difference in $-\tau^{(x)} / f$. All quantities are zonally averaged over the width of the Atlantic Ocean.

heat content are mainly brought about by the surface heat flux. The transport divergence represents only a minor term in the heat budget. The present experiments suggest that the annual variation of northward heat transport in the subtropical North Atlantic is only weakly dependent on model resolution but very sensitive to the wind stress climatology; the maximum variation in the case of $\mathrm{IH}$ forcing is found at $27^{\circ} \mathrm{N}$ with $0.77 \mathrm{PW}$, up from $0.53 \mathrm{PW}$ at $34^{\circ} \mathrm{N}$ in the case of HR forcing (Table 1).

There is little in the way of observational data that could provide a direct, quantitative test of these model results. Indirect studies of the annual cycle of oceanic heat transport based on the energy flux at the air-sea interface, most recently by Hsiung et al. (1989), are faced with the problem that in the seasonal heat budget of extratropical regions the transport divergence represents a rather small residual of the surface heat flux and the change of oceanic heat storage. Even relatively small errors in these two terms can thus have a large impact on the inferred transport divergences. The uncertainty in the meridional heat transport, obtained by integrating these divergences over the polar cap, increases monotonically southward. Isemer et al. (1989) noted that an error of $20 \mathrm{~W} \mathrm{~m}^{-2}$ in net surface heat flux corresponds to an error of about $0.5 \mathrm{PW}$ in mean meridional heat transport at $25^{\circ} \mathrm{N}$, and $0.8 \mathrm{PW}$ at the equator. Hsiung et al. (1989) estimated uncertainties of their monthly heat transports of $0.5 \mathrm{PW}$ in the subtropical North Atlantic, increasing to $0.7 \mathrm{PW}$ at the equator. Given this error range, the model results for the subtropical North Atlantic are not significantly different from the annual cycle derived by Hsiung et al. (1989) (Fig. 2). The result with IH forcing seems to better capture the observed amplitude; however, due to the existing uncertainties of the observations, it is 

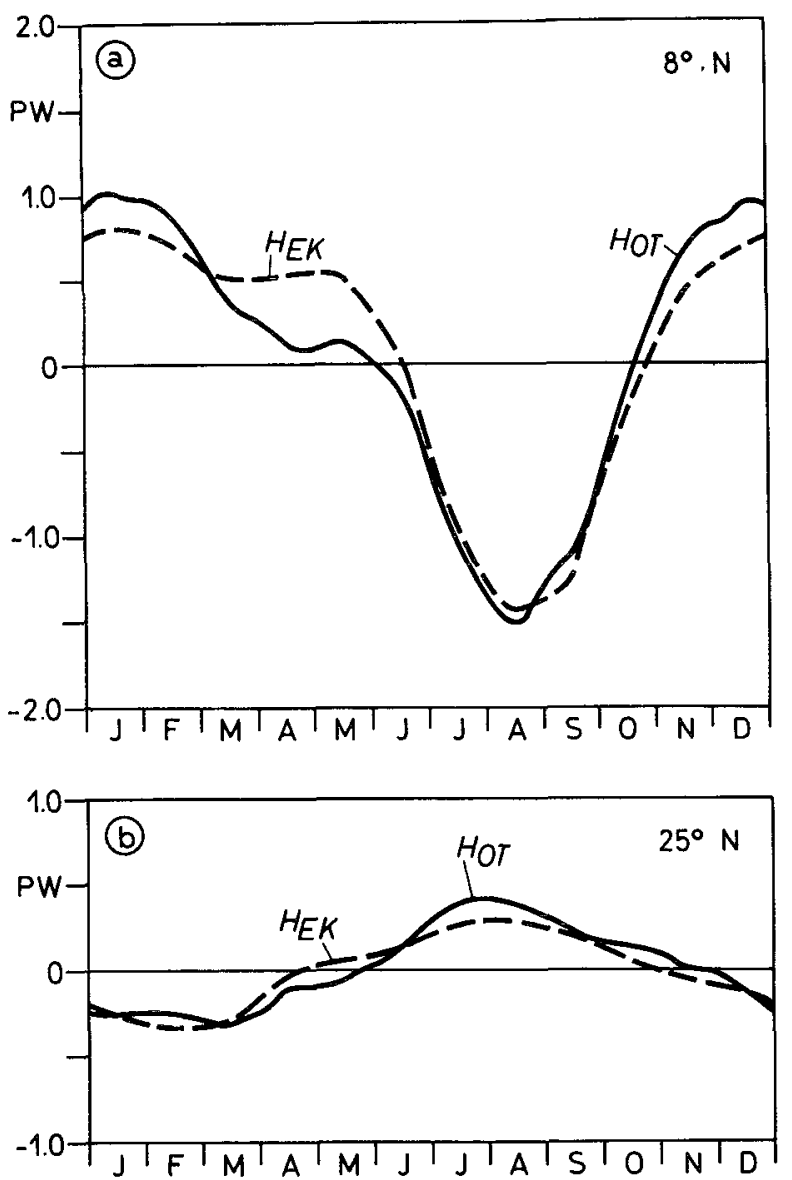

FIG. 13. Mean annual cycle of the northward heat transport contribution from meridional overturning $H_{\mathrm{OT}}$, compared with the formal expression for the Ekman effect $H_{\mathrm{Ek}}$, at (a) $8^{\circ} \mathrm{N}$ and (b) $25^{\circ} \mathrm{N}$.

difficult to assess the validity of the different model versions.

The mechanism of the seasonal variation in heat transport in the present model can be understood in terms of volume transport variations in the meridionalvertical plane. As in the earlier, coarse-resolution model studies of Bryan (1982) and Sarmiento (1986), the effect of variations in horizontal gyre transport remains comparatively small, both in the equatorial and in the subtropical Atlantic. The meridional circulation changes in the surface layer are induced by the seasonal variation of zonal wind stress; these Ekman transport anomalies are compensated by return flows in the deep ocean. Perhaps the most intriguing aspect of the model solutions is the vertical structure of the seasonal anomalies in the zonally integrated overturning motion: except for a narrow equatorial zone, the compensatory flow is only weakly depth dependent; it gives the impression of an approximately barotropic response of the deep ocean to the variability in the surface layer. A similar behavior had been noted already in the model analysis of Bryan (1982). It is consistent with theoret-
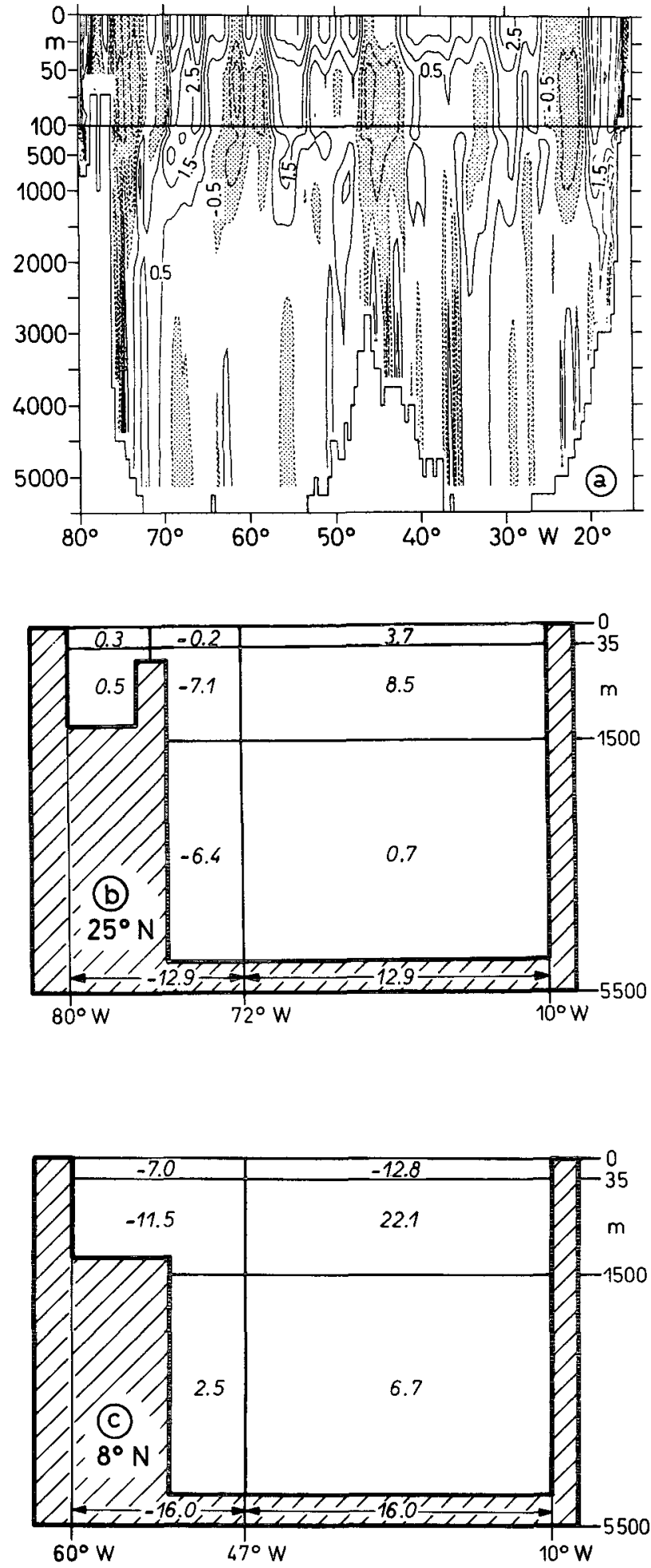

FIG. 14. (a) Difference in the meridional velocity component (in $\mathrm{cm} \mathrm{s}^{-1}$ ) between July and January, along the zonal section $25^{\circ} \mathrm{N}$. Areas with southward velocity exceeding $0.5 \mathrm{~cm} \mathrm{~s}^{-1}$ are shaded. (b) Difference in meridional volume transports (in $10^{6} \mathrm{~m}^{3} \mathrm{~s}^{-1}$ ) between summer (Jul-Aug-Sep) and winter (Jan-Feb-Mar), through subsections at $25^{\circ} \mathrm{N}$. (c) Same as in (b) for $8^{\circ} \mathrm{N}$. 
ical considerations (Gill and Niiler 1973) and model studies (e.g., Anderson et al. 1979) of the ocean's response to time-dependent forcing; due to the small phase speed of baroclinic Rossby waves away from the equatorial waveguide, no baroclinic compensation to surface forcing can be expected at seasonal or shorter time scales. Since a barotropic response of the ocean to variations in surface forcing is established within a few days, a similar type of variation in meridional overturning and heat transport as seen on the seasonal time scale could also be expected on synoptic time scales. Indeed, preliminary results from an experiment forced with daily wind stresses from the European Centre for Medium-Range Weather Forecasts (Expt. 5 in the Kiel CME sequence) indicate a considerable variability in meridional heat transport on a time scale of weeks. Its amplitude in midlatitudes is strongest in winter and exceeds the annual signal. The patterns of zonally integrated volume transport associated with these variations are of much smaller meridional extent than the seasonal overturning anomalies but they indicate a similar, weakly depth-dependent response in the deep ocean.

The deep velocity signal associated with the seasonal transport variations is on the order of a millimeters per second over most parts of the ocean, not detectable in actual measurements against the much stronger eddy noise. It seems that the validity of the model response to seasonal forcing can only be assessed by consistency checks against the transport variations observed at the western boundary. The annual cycle of transport through the Florida Straits is known quite well from a number of observational studies (e.g., Larsen 1992) and is reasonably reproduced in the CME experiments (Böning et al. 1991a). However, as that and other model studies indicated, the annual cycle in the straits represents an effect of regional wind forcing over the continental shelf and is decoupled from the transport variations occurring in the deep ocean. Measurements to the east of the Bahamas by Lee et al. (1990) gave no indication of a seasonal signal but did give one of a strong, barotropic variability of the boundary current transport on subseasonal time scales. It seems unclear at present whether that large, stochastic variability, also found in the CME model (Böning et al. 1991a), masks the smaller signal that is expected from the seasonal wind forcing. A significant annual signal was also not detected in recent year-long deep current measurements in the western equatorial Atlantic (Schott et al. 1993). Again, the presence of an annual signal of a few centimeters per second amplitude hidden in the strong eddy signal cannot be excluded on the present observational basis.

The vertical structure of the wind-induced overturning anomalies bears a strong implication for the magnitude of the associated heat transports. The model results are not consistent with the assumption of Bryden et al. (1991) that the seasonal response of the ocean should be confined to the upper $700 \mathrm{~m}$. Instead, the model analysis suggests that a first approximation of the seasonal heat transport variations in the ocean may be obtained with a simple calculation of the Ekman effect as proposed by Kraus and Levitus (1986). The main uncertainty in such estimates of the seasonal cycle arises from the poor knowledge of the wind stresses and resulting Ekman transports. Based on the $\mathrm{IH}$ stresses, the annual range in the subtropical North Atlantic is nearly as large as the mean meridional transport of heat. However, whatever the actual value, all model results consistently show that the large seasonal variation in meridional transport of heat does not contribute to the changes in the heat storage in extratropical regions. In those regions it may also be of little consequence for the calculation of mean heat transports by the direct method: Due to the barotropic nature of the deep oceanic response to forcing at seasonal and shorter time scales, the geostrophic shear observed in one-time hydrographic sections should still reflect, to a large degree, the annual mean conditions.

Acknowledgments. We are grateful to F. Bryan and W. Holland who generously provided the model code and shared their experience from the initial experiments of the U.S. WOCE Community Modeling Effort. Thanks are due to R. Budich and R. Döscher for help in running and analyzing the model experiments at the CRAY X-MP of Kiel University. This work is supported by the Deutsche Forschungsgemeinschaft, SFB 133.

\section{REFERENCES}

Anderson, D. L. T., and R. A. Corry, 1985: Ocean response to lowfrequency wind forcing with application to the seasonal variation in the Florida Straits-Gulf Stream transport. Progress in Oceanography, Vol 14, Pergamon.

—_, K. Bryan, A. E. Gill, and R. C. Pacanowski, 1979: The transient response of the North Atlantic: Some model studies. J. Geophys. Res., 84, 4795-4815.

Böning, C. W., R. Döscher, and R. G. Budich, 199 la: Seasonal transport variation in the western subtropical North Atlantic: Experiments with an eddy resolving model. J. Phys. Oceanogr., 21, $1271-1289$.

$\ldots,-$, and H.-J. Isemer, $199 \mathrm{lb}$ : Monthly mean wind stress and Sverdrup transport in the North Atlantic: A comparison of the Hellerman-Rosenstein and Isemer-Hasse climatologies. J. Phys. Oceanogr., 21, 221-239.

Bryan, F. O., and W. R. Holland, 1989: A high resolution simulation of the wind- and thermohaline-driven circulation in the North Atlantic Ocean. Parameterization of Small-scale Processes. Proc. 'A ha huliko'a, Hawailan Winter Workshop, University of Hawaii, 99-115.

- K., 1969: A numerical method for the study of the circulation of the World Ocean. J. Comput. Phys., 4, 347-376.

- 1 1982: Seasonal variation in meridional overturning and poleward heat transport in the Atlantic and Pacific Oceans: a model study. J. Mar. Res., 40, 39-53.

J. Geophys. Res., 84, 2503-2517.

Bryden, H. L., D. H. Roemmich, and J. A. Church, 1991: Ocean heat transport across $24^{\circ} \mathrm{N}$ in the Pacific. Deep Sea Res., 38, 297-324. 
Camp, N. T., and R. L. Elsberry, 1978: Oceanic thermal response to strong atmospheric forcing II. The role of one-dimensional processes. J. Phys. Oceanogr., 8, 215-224.

Carissimo, B. C., A. H. Oort, and T. H. Vonder Haar, 1985: Estimates of the meridional energy transports in the atmosphere and ocean. J. Phys. Oceanogr., 15, 82-91.

Cox, M. D., 1984: A primitive equation, 3-dimensional model of the ocean. GFDL Ocean Group Technical Report No. 1, GFDL/ Princeton University. 143 pp.

Didden, N., and F. Schott, 1992: Seasonal variations in the western tropical Atlantic: Surface circulation from GEOSAT altimetry and WOCE model results. J. Geophys. Res., 97, 3529-3542.

Döscher, R., C. W. Böning, and P. Herrmann, 1993: Response of meridional overturning and heat transport in the North Atlantic to changes in thermohaline forcing in northern latitudes: A model study, submitted.

Garzoli, S. L., and E. J. Katz, 1983: The forced annual reversal of the Atlantic North Equatorial Countercurrent. J. Phys. Oceanogr., 13, 2082-2090.

Gill, A. E., and P. P. Niiler, 1973: The theory of the seasonal variability in the ocean. Deep Sea Res., 20, 141-178.

Hall, M. M., and H. L. Bryden, 1982: Direct estimates and mechanisms of ocean heat transport. Deep Sea Res., 29, 339-359.

Han, Y.-J., 1984: A numerical world ocean circulation model. Part II: A baroclinic experiment. Dyn. Atmos. Oceans, 8, 141-172.

Haney, R. L., 1971: Surface thermal boundary condition for ocean circulation models. J. Phys. Oceanogr., 1, 241-248.

Hellerman, S., 1967: An updated estimate of the wind stress in the World Ocean. Mon. Wea. Rev., 95, 607-626.

the world ocean with error estimates. J. Phys. Oceanogr., 13, 1093-1104.

Holland, W. R., and F. O. Bryan, 1993: Sensitivity studies on the role of the ocean in climate change. Ocean Processes in Climate Dynamics: Global and Mediterranean Examples. P. MalanotteRizzoli and A. R. Robinson, Eds. NATO ASI Proceedings, Kluwer, in press.

Hsiung, J., R. E. Newell, and T. Houghtby, 1989: The annual cycle of oceanic heat storage and ocean meridional heat transport. Quart. J. Roy. Meteor. Soc., 115, 1-28.

Isemer, H.-J., and L. Hasse, 1987: The Bunker Climate Atlas of the North Atlantic Ocean Vol. 2: Air-Sea Interactions. Springer Verlag, $256 \mathrm{pp}$.

,-- , and J. Willebrand, 1989: Fine adjustment of large scale air-sea energy flux parameterizations by direct estimates of ocean heat transport. J. Climate, 2, 819-836.
Kraus, E. B., and S. Levitus, 1986: Annual heat flux variations across the tropic circles. J. Phys. Oceanogr., 16, 1479-1486.

Lamb, P. J., 1981: Estimate of annual variation of Atlantic Ocean heat transport. Nature, 290, 766-768.

of the North and tropical Atlantic Oceans. J. Phys. Oceanogr., 12, 1388-1409.

Larsen, J. C., 1992: Transport and heat flux of the Florida Current at $27^{\circ} \mathrm{N}$ derived from cross-stream voltages and profiling data: Theory and observation. Phil. Trans. Roy. Soc. London, A338, 169-236.

Lee, T. N., W. Johns, F. Schott, and R. Zantopp, 1990: Western boundary current structure and variability east of Abaco, Bahamas, at $26.5^{\circ}$ N. J. Phys. Oceanogr., 20, 446-466.

Levitus, S., 1982: Climatological atlas of the world ocean, NOAA Prof. Paper 13, U.S. Govt. Printing Office, 173 pp.

- 1984: Annual cycle of temperature and heat storage in the world ocean. J. Phys. Oceanogr., 14, 727-746.

Meehl, G. A., W. M. Washington, and A. J. Semtner, Jr., 1982: Experiments with a global ocean model driven by observed atmospheric forcing. J. Phys. Oceanogr., 12, 301-312.

Merle, J., 1980: Seasonal heat budget in the equatorial Atlantic Ocean. J. Phys. Oceanogr., 10, 464-469.

Molinari, R. L., E. Johns, and J. F. Festa, 1990: The annual cycle of meridional heat flux in the Atlantic Ocean at $26.5^{\circ} \mathrm{N}$. J. Phys. Oceanogr., 20, 476-482.

Oort, A. H., and T. H. Vonder Haar, 1976: On the observed annual cycle in the ocean-atmosphere heat balance over the Northern Hemisphere. J. Phys. Oceanogr., 6, 781-800.

Philander, G., and R. C. Pacanowski, 1986a: A model of the seasonal cycle in the tropical Atlantic Ocean. J. Geophys. Res., 91, $14192-14206$.

$\longrightarrow$, and - 1986b: The mass and heat budget in a model of the tropical Atlantic Ocean. J. Geophys. Res., 91, 14 212-14 220.

Roemmich, D., and C. Wunsch, 1985: Two transatlantic sections: meridional circulation and heat flux in the subtropical North Atlantic Ocean. Deep Sea Res., 32, 619-664.

Sarmiento, J. L., 1986: On the North and Tropical Atlantic heat balance. J. Geophys. Res., 91, 11 677-11 689.

Schott, F. A., and C. W. Böning, 1991: Evaluation of the WOCE model in the western equatorial Atlantic: Upper-layer circulation. J. Geophys. Res., 96, 6993-7004.

- J. Fischer, J. Reppin, and U. Send, 1993: On mean and seasonal currents and transports at the western boundary of the equatorial Atlantic. J. Geophys. Res., 98, 14 353-14 368.

Vonder Haar, T. H., and A. H. Oort, 1973: New estimate of annual poleward energy transport by Northern Hemisphere oceans. $J$. Phys. Oceanogr., 2, 169-172. 